\title{
Effect of fabric parameters on fragrance retention
}

DOI: 10.35530/IT.071.05.1729

LEI DU

WEI-GUO ZHAO

FU-XIANG WANG

FENG-YUAN ZOU

JIA-LI YANG

ZHUO-YING SHEN

HAI-FENG ZHU

SU-HONG XU

\section{ABSTRACT - REZUMAT}

\section{Effect of fabric parameters on fragrance retention}

This study is to explore the effect of fabric parameters on fragrance retention, which was based on the olfactory measurement technology with the quantitative headspace method. The fragrance retention of different fabrics was quantitatively evaluated by Electronic Nose (e-nose) at different time after volatilization. Quick-drying Tester was used to test the fabric drying rate, which was related to fragrance retention. Besides, wicking property and porosity of fabrics, two factors of moisture transmission, were tested and calculated for analysis too. It was found that fabrics with the higher cotton content had the better fragrance retention due to their hydrophilicity and water retention property of fibers. Plain fabric had the shorter fragrance retention than twill fabric since its lower porosity and the higher capillary pressure led to the faster fragrance dissipation. As the fabric density increased or the yarn count decreased, the fragrance retention increased. Since their wicking properties decreased, the process of perfume diffusion would slow down. The data and methods presented in this paper provide a basis for optimizing the parameters of fragrant fabric.

Keywords: fabric parameters, fragrance retention, electronic nose, moisture transmission, wicking property, quick-drying tester

\section{Influența caracteristicilor materialului textil asupra retenției parfumului}

Acest studiu analizează influența caracteristicilor materialului textil asupra retenției parfumurilor, care s-a bazat pe tehnologia de măsurare olfactivă cu metoda cantitativă a spațiului liber. Retenția parfumului diferitelor materiale textile a fost evaluată cantitativ prin Electronic Nose (e-nose), la diferite momente după volatilizare. Testerul cu uscare rapidă a fost folosit pentru a testa rata de uscare a materialului textil, care a fost corelată cu retenția parfumului. În plus, proprietatea de absorbție și porozitatea materialelor textile, doi factori de transmitere a umidității, au fost testate și calculate pentru analiză. S-a constatat că materialele textile cu un conținut mai ridicat de bumbac înregistrează o mai bună retenție a parfumului, datorită proprietății de hidrofilitate și de retenție a apei din fibre. Țesătura cu legătură pânză a avut o retenție de parfum mai redusă, decât țesătura cu legătură diagonal, deoarece porozitatea sa este mai mică și presiunea capilară este mai mare, ce a condus la disiparea mai rapidă a parfumului. Pe măsură ce desimea țesăturii a crescut sau finețea firului a scăzut, retenția parfumului a crescut. Deoarece proprietățile lor de absorbție au scăzut, procesul de difuzare a parfumului a fost încetinit. Datele și metodele prezentate în această lucrare oferă o bază pentru optimizarea caracteristicilor materialelor textile parfumate.

Cuvinte-cheie: caracteristicile țesăturii, retenția parfumului, "electronic nose", transmiterea umidității, proprietate de absorbție, tester cu uscare rapidă

\section{INTRODUCTION}

Nowadays, perfume is widely used in people's daily life. It can satisfy wearers and leave a deep impression on others [1, 2]. Also, such undesirable smells as sweat and hircismus can be covered up [3]. Besides, it was reported that fragrances have the functions of sedation, sterilization, hypnosis, health care, and so forth [4]. However, according to researches, there were negative effects spraying directly on the skin, such as allergenic potential or other skin diseases $[5,6]$. Therefore, it seems that perfume is more suitable to be used on clothes. At present, the methods of adding fragrance to textiles include coating, microcapsule finishing and aromatic fibers preparing [7], which can only produce a single fragrance. But consumers have different fragrance pursuits for different occasions and moods. Therefore, spraying perfume on clothing directly has a more practical significance. However, it needs further exploration of how to prolong the fragrance retention, which is an effective and natural way to delight customers.

As a new testing item, the detection of aromatic textiles is in the stage of continuous exploration and gradual development. Previously, the odour detection and evaluation of textiles used to be carried out by experts after olfactory training [8]. But these experts were easy to be affected by subjective factors. Now, Electronic nose (e-nose), known as odour fingerprint detector, is often applied to detect, identify, and analyse volatile components [9]. E-nose works with a series of sensors. The composition of the volatile analytes can be judged based on the corresponding 
resistor value $\left(\mathrm{G} / \mathrm{G}_{0}\right)$ of sensors [10]. E-nose has been widely used in the food industry, tobacco identification, medical diagnosis, environmental protection, textile industry, and other fields [11-15]. In addition, headspace method was often used for volatile extraction [16]. Thus, it is advisable to utilize the olfactory measurement technology (i.e. e-nose) with quantitative headspace method in this study.

The fragrance retention may be associated with moisture transmission, while which is further related to the type of fabric. In this study, the fragrance retention would be explored by using e-nose with the quantitative headspace method. Furthermore, to reveal the relationship between fragrance retention and moisture transmission, the drying rate, the wicking property, and the porosity of fabrics were tested and calculated. The fabric parameters involved in material composition, fabric weave, fabric density, and yarn count, they were analysed separately under the same conditions.

\section{EXPERIMENTAL}

\section{Materials}

Fabrics, each differing in material composition, fabric weave, fabric density, and yarn count were used. All of them were bought from Linya Textile Co. Ltd, China. Their specific parameters are listed in table 1. All these undyed fabrics were rinsed and dried before experiment. Generally, perfume consisted of top, middle and base notes [17]. Fruity top note had a relatively short volatilization time (i.e. about 3 hours) and single fragrant base would not change in tonality, both of which were advantageous to the detection of experiments [18]. Additionally, odour-free alcohol was often applied to configure perfume. Thus, the fruity base of grapefruit (Eprhan Spices Co., Ltd., China) and the odour-free alcohol (concentration 95\%, Gold Alcohol Chemical Co. Ltd, China) were selected as raw materials.

Table 1

\begin{tabular}{|c|c|c|c|c|}
\hline \multicolumn{4}{|c|}{ DIFFERENT FABRIC PARAMETERS } \\
\hline $\begin{array}{c}\text { Fabric } \\
\text { number }\end{array}$ & $\begin{array}{c}\text { Material } \\
\text { composition }\end{array}$ & $\begin{array}{c}\text { Fabric } \\
\text { weave }\end{array}$ & $\begin{array}{c}\text { Fabric } \\
\text { density } \\
\text { (count/ } \\
10 \text { cm) }\end{array}$ & $\begin{array}{c}\text { Yarn } \\
\text { count } \\
\text { (Ne) }\end{array}$ \\
\hline Sample \# 1 & $100 \%$ Cotton & Plain & $524 \times 283$ & 40 \\
\hline Sample \# 2 & $\begin{array}{c}35 \% \text { Cotton/ } \\
65 \% \text { Polyester }\end{array}$ & Plain & $524 \times 283$ & 45 \\
\hline Sample \# 3 & $\begin{array}{c}10 \% \text { Cotton/ } \\
90 \% \text { Polyester }\end{array}$ & Plain & $524 \times 283$ & 45 \\
\hline Sample \# 4 & $100 \%$ Cotton & Twill & $524 \times 283$ & 40 \\
\hline Sample \# 5 & $100 \%$ Cotton & Plain & $524 \times 394$ & 40 \\
\hline Sample \# 6 & $100 \%$ Cotton & Plain & $433 \times 283$ & 40 \\
\hline Sample \# 7 & $100 \%$ Cotton & Plain & $276 \times 197$ & 40 \\
\hline Sample \# 8 & $100 \%$ Cotton & Plain & $524 \times 283$ & 32 \\
\hline Sample \# 9 & $100 \%$ Cotton & Plain & $524 \times 283$ & 21 \\
\hline
\end{tabular}

\section{Perfume preparation}

The experiments were carried out under the condition of constant temperature and humidity (i.e. $25 \pm 2{ }^{\circ} \mathrm{C}$ with humidity of $30 \pm 3 \%$ ). The fruity base was serially diluted with odor-free alcohol until the resistor values $\left(G / G_{0}\right)$ of e-nose (PEN3, Airsense Analytics $\mathrm{GmbH}$, Germany) displayed stably. The main applications of sensors in PEN3 are listed in table 2 [19]. The resistor value $\left(\mathrm{G} / \mathrm{G}_{0}\right)$ of sensor No. 9 was selected, since its response to the fragrance was the strongest in the experiment. In the remainder of this article, the resistor value $\left(G / G_{0}\right)$ of sensor No. 9 will be referred to as "R9". When R9 was within 10 and the resistor values stayed stable, the ratio of fruity base and odour-free alcohol was 1:79.

Table 2

SENSORS USED AND THEIR MAIN APPLICATIONS IN PEN3

\begin{tabular}{|c|c|l|}
\hline $\begin{array}{c}\text { Number } \\
\text { in array }\end{array}$ & Sensor-name & \multicolumn{1}{|c|}{$\begin{array}{c}\text { Object substances } \\
\text { for sensing }\end{array}$} \\
\hline MOS 1 & W1C & Aromatic compounds \\
\hline MOS 2 & W5S & Nitrogen oxides \\
\hline MOS 3 & W3C & $\begin{array}{l}\text { Ammonia, aromatic } \\
\text { compounds }\end{array}$ \\
\hline MOS 4 & W6S & Hydrogen \\
\hline MOS 5 & W5C & $\begin{array}{l}\text { Alkanes, less polar } \\
\text { compounds }\end{array}$ \\
\hline MOS 6 & W1S & $\begin{array}{l}\text { Sensitive to methane } \\
\text { (environment), broad range }\end{array}$ \\
\hline MOS 7 & W1W & $\begin{array}{l}\text { Sulfur compounds, } \\
\text { terpenes, sulfur organic } \\
\text { compounds }\end{array}$ \\
\hline MOS 8 & W2S & $\begin{array}{l}\text { Detects alcohol's, broad } \\
\text { range, Ssimilar to MOS 6 }\end{array}$ \\
\hline MOS 9 & W2W & $\begin{array}{l}\text { Aromatic compounds, sulfur } \\
\text { organic compounds }\end{array}$ \\
\hline MOS 10 & W3S & $\begin{array}{l}\text { Reacts on high concentra- } \\
\text { tions }>100 \text { ppm, Sometimes } \\
\text { very selective (methane) }\end{array}$ \\
\hline
\end{tabular}

\section{Exploration of experiment parameters}

Four sizes of swatches (i.e. $6 \mathrm{~cm}, 7 \mathrm{~cm}, 8 \mathrm{~cm}, 9 \mathrm{~cm}$ ) were placed at the bottom of the corresponding four specifications of beakers (i.e. $250 \mathrm{ml}, 500 \mathrm{ml}, 800 \mathrm{ml}$, $1000 \mathrm{ml}$ ). Then, perfume with three dosages (i.e. $50 \mu \mathrm{l}, 100 \mu \mathrm{l}, 200 \mu \mathrm{l}$ ), taken by the pipette (F3, 20-200 $\mu$, Thermo Fisher Scientific, America), was evenly dropped onto four swatches respectively. Finally, e-nose was used to select the suitable samples. The size of beaker and swatch depends on each other, and the area of swatch further determines the amount of perfume. Moreover, the perfume droplets applied to the fabric ought to spread evenly and do not overlap. Results manifested that the $6 \mathrm{~cm}, 7 \mathrm{~cm}$ and $8 \mathrm{~cm}$ diameter circular swatches applied with $50 \mu \mathrm{l}$ perfume respectively, and the $9 \mathrm{~cm}$ diameter circular swatches applied with $50 \mu$ or $100 \mu$ perfume were able to obtain stable and reliable results. 
Furthermore, from the R9, it was found that $50 \mu \mathrm{l}$ perfume had a steady trend prematurely (i.e. $30 \mathrm{~min}$ ), while the usage of $100 \mu$ l stepped down within 60 min, which was more conducive to detect. Thus, 100 $\mu \mathrm{l}$ perfume was chosen as the experimental parameter. Meanwhile, the swatch with the diameter of $9 \mathrm{~cm}$ and the beaker size (i.e. $1000 \mathrm{ml}$ ) were selected. Besides, the large beaker is also more beneficial to the extraction of headspace air.

The same amount of perfume was dropped onto four fabrics having the same parameters. After volatilizarespectively for different time (i.e. $5 \mathrm{~min}, 10 \mathrm{~min}, 15$ min and $18 \mathrm{~min}$ ). By observing R9, the sealing time would be determined when fragrance was full of beaker. The curve of R9 was fitted at stability (i.e. at 60-80 s). As shown in table 3, the fragrance filled the beaker completely at $15 \mathrm{~min}$, since its R9 was the highest and its curve fitting slope of R9 tended to 0 . Thus, 15 min was selected as the sealing time.

The samples were detected by e-nose per hours to find out the range of detection time. The sampling 180 min respectively. According to the detection, R9 dropped sharply within $60 \mathrm{~min}$, but its rate declined from 60 to $180 \mathrm{~min}$. Moreover, R9 tended to be constant at $180 \mathrm{~min}$. Therefore, the detection time was separately set as $10 \mathrm{~min}, 20 \mathrm{~min}, 30 \mathrm{~min}, 40 \mathrm{~min}, 50$ $\mathrm{min}, 60 \mathrm{~min}, 90 \mathrm{~min}, 120 \mathrm{~min}$ and $180 \mathrm{~min}$, a total of 9 detection time points.

\section{Testing on fragrance retention of fabrics by e-nose}

Based on the above experimental parameters, $100 \mu \mathrm{l}$ perfume was evenly dropped onto the $9 \mathrm{~cm}$ diameter swatch which was placed at the bottom of the $100 \mathrm{ml}$ beaker. After the same 9 swatches separately volatilizing for different detection time, the beaker was sealed with plastic wrap for $15 \mathrm{~min}$. The headspace air of the beaker was detected by e-nose to obtain R9. A total of five experiments were performed on each sample. Detailed information of the experiment groups is provided in table 4. tion for $10 \mathrm{~min}$, these fabrics were sealed in beakers time was preliminarily set as $60 \mathrm{~min}, 120 \mathrm{~min}$ and

\section{Testing of fabric drying rate}

The water evaporation rate and time were achieved through Quick-drying Tester (DST-5200B, Daiei Kagaku Seiki Mfg. Co., Ltd., Japan). The time interval was present to $1 \mathrm{~min}$ since fragrance has a strong ability of volatility. $200 \mu$ l perfume was evenly dropped onto swatch. Then, the test was conducted in accordance with the GB/T 21655.1. All fabrics were tested five times in sequence. And their water evaporation rates were recorded based on the peak of the "time-evaporation" graph.

\section{Testing on wicking properties of fabrics}

The absorbability of fabric, which reflects the wicking property, was measured by Automatic Water Absorption Speed Tester (PW-5P-AT2, Daiei Kagaku Seiki Mfg. Co., Ltd., Japan). According to JIS L 1907, the water absorption speed was evaluated by automatically-measured water rising height in $10 \mathrm{~min}$, which was denoted as sample \# X $H_{\text {wrap }}, H_{\text {weft }}$. Each fabric was tested five times.

\section{RESULTS AND DISCUSSION}

The effect of material composition on fragrance retention

As shown in figure 1, the fragrance retention of fabrics was proportional to the cotton content. At the same time, with the proportion of cotton decreasing, the drying rate of fabric increased (figure 2). While, another evaluation of the drying time, peak decreased (figure 2). It was reported that the drying rate of fabrics depended on the moisture content of fibers, which relied on their hydrophilicity and water retention property [20]. Cotton fibers had the better hydrophilicities since their surface had more bonding sites for water molecules than polyester [21]. Besides, the irregular shape of cotton fibers contributed to the better water retention property [22]. What's more, according to the optical microscope images of yarns (figure 3), the yarn hairiness became much messy as the cotton content increased leading to less moisture transmission. Additionally, when the fragrance was absorbed by Table 3

\begin{tabular}{|l|c|c|c|c|}
\hline \multicolumn{5}{|c|}{ RESPONSE OF SENSOR 9 AT DIFFERENT SEALING TIME } \\
\hline Sealing time $(\mathrm{min})$ & 5 & 10 & 15 & 18 \\
\hline Resistor values $\left(\mathrm{G} / \mathrm{G}_{0}\right)$ & 3.605 & 4.693 & 5.063 & 2.414 \\
\hline Curve fitting slope $(60-80 \mathrm{~s})$ & 0.03882 & 0.02085 & -0.00036 & -0.00305 \\
\hline
\end{tabular}

Table 4

\begin{tabular}{|c|c|c|c|c|}
\hline \multicolumn{5}{|c|}{ EXPERIMENT GROUPS WITH DIFFERENT FABRIC PARAMETERS } \\
\hline No. & Experimental variable & \multicolumn{3}{c|}{ Fabric number } \\
\hline Group 1 & Material composition & Sample \# 1 & Sample \# 2 & Sample \# 3 \\
\hline Group 2 & Fabric weave & Sample \# 1 & - & Sample \# 4 \\
\hline Group 3 & Fabric density (count/10 cm) & Sample \# 5 & Sample \# 6 & Sample \# 7 \\
\hline Group 4 & Yarn count $(\mathrm{Ne})$ & Sample \# 1 & Sample \# 8 & Sample \# 9 \\
\hline
\end{tabular}

fibers, the fibers swelled up and the size of air spaces narrowed down, thereby slowing down the diffusion process [23]. On the other hand, the wicking property was inversely proportional to the cotton content in accordance with the test results (i.e. sample \# $1 H_{\text {wrap }}=70.1 \pm$ $1.3 \mathrm{~mm}, H_{\text {weft }}=57.4 \pm 1.1$ $\mathrm{mm}$; sample \# $2 H_{\text {wrap }}=89 \pm$ $1.5 \mathrm{~mm}, H_{\text {weft }}=72.27 \pm 1.1$ $\mathrm{mm}$; sample \# $3 H_{\text {wrap }}=94.47$ $\pm 1.7 \mathrm{~mm}, H_{\text {weft }}=75.87 \pm 1.3$ $\mathrm{mm})$. It meant that polyester 
fiber was favourable to the moisture transmission, resulting in the shorter fragrance retention. Therefore, in summary, samples with the higher cotton content would have a slower drying rate, allowing the fragrance to remain longer.

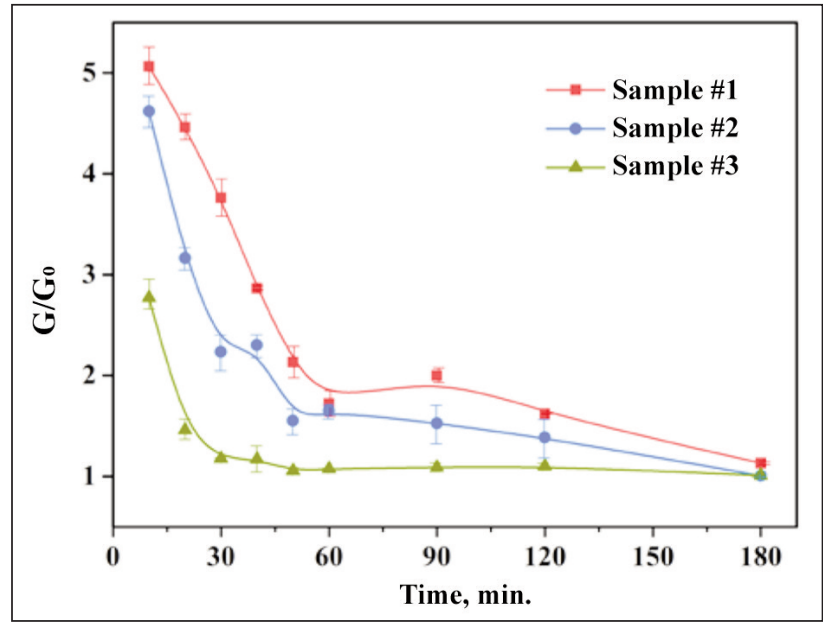

Fig. 1. The resistor value of different material compositions

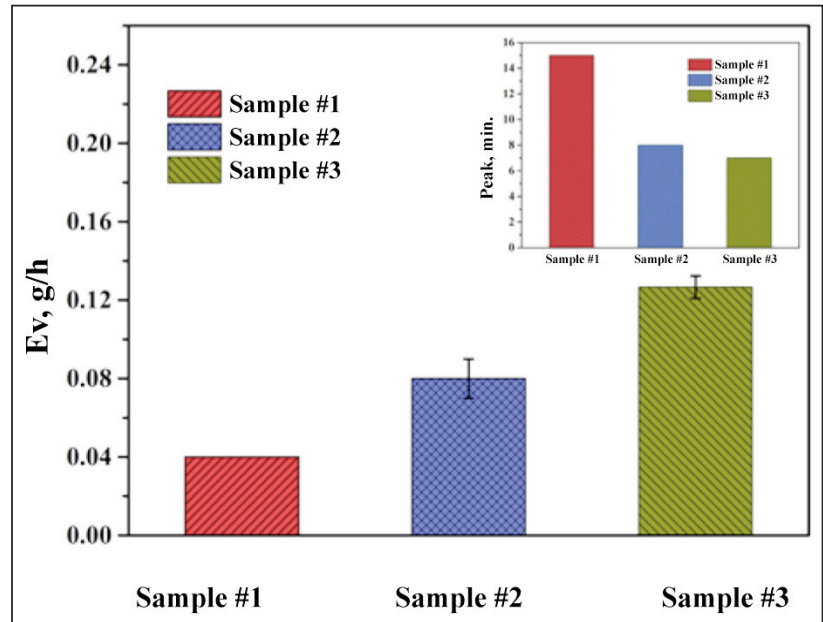

Fig. 2. The drying rate $\mathrm{Ev}(\mathrm{g} / \mathrm{h})$ of different material compositions and the inset is the corresponding peak (min)

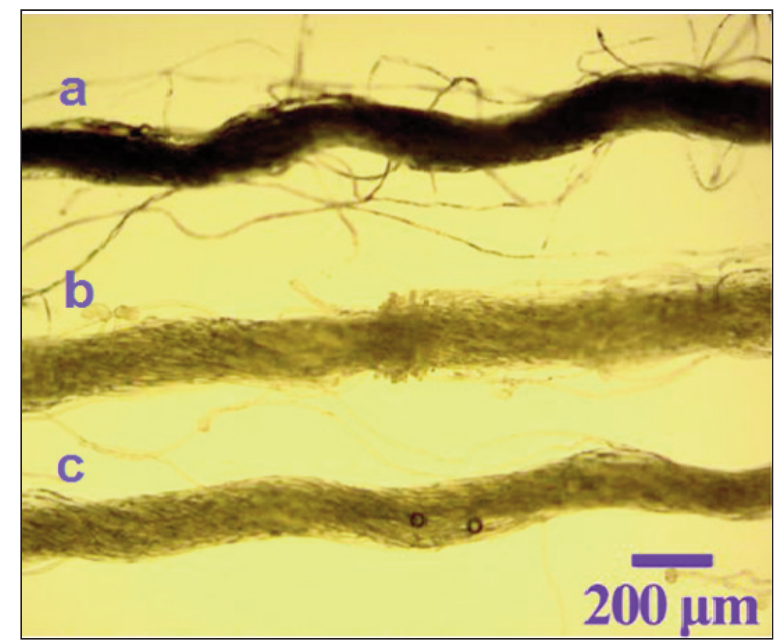

Fig. 3. The optical microscope image of yarns with different material compositions: a - sample \# 1; b - sample \# 2; $c$ - sample \# 3
The effect of fabric weave on fragrance retention The R9 for plain and twill fabric is shown in figure 4 . It reflects that the value of twill fabric was higher than the plain fabric, and both of their fragrance reduced over time. As drying rates diversity is not obvious, the peak of two fabrics is shown in the inset of figure 5 . It is noticeable that twill fabric required a longer time for drying, indicating a better fragrance retention. It is widely accepted that the liquid transfer mechanism included capillary wicking which was associated with the fabric porosity [20]. The porosity of plain fabric was lower than twill fabric based on the equation 1 (i.e. $\varepsilon_{\text {plain }}=0.679 \%, \varepsilon_{\text {twill }}=0.698 \%$ ) [24], which is in agreement with the findings presented by Atasağun's report [25]:

$$
\begin{gathered}
\varepsilon=\frac{V_{\text {pores }}}{V_{\text {fabric }}} \cdot 100=\left(1-\frac{\rho_{\text {fabric }}}{\rho_{\text {fiber }}}\right) \cdot 100= \\
=\left(1-\frac{M_{\text {fabric }}}{T_{\text {fabric }} \cdot 1000 \cdot \rho_{\text {fiber }}}\right) \cdot 100
\end{gathered}
$$

where $\varepsilon$ is the total porosity (\%), $V_{\text {pores }}$ - the volume of pores in woven fabrics $\left(\mathrm{cm}^{3}\right), V_{\text {fabric }}$ - the volume of woven fabric $\left(\mathrm{cm}^{3}\right) . \rho_{\text {fabric }}$ and $\rho_{\text {fiber }}$ represent physical

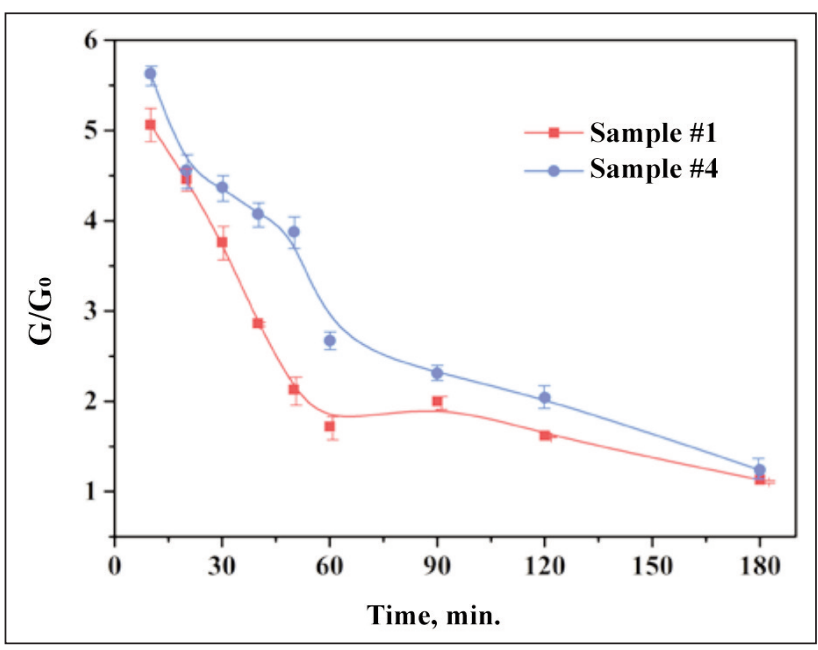

Fig. 4. The resistor value of different fabric weave

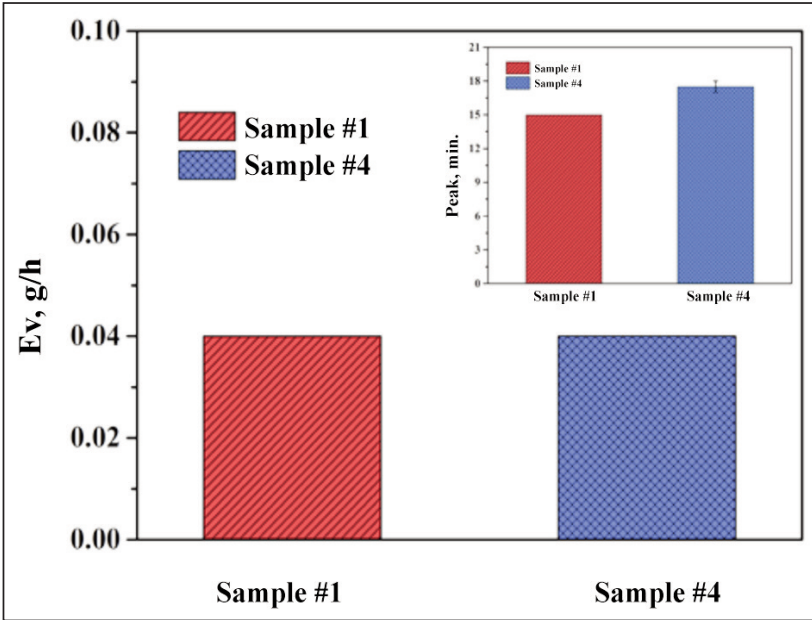

Fig. 5. The drying rate Ev $(\mathrm{g} / \mathrm{h})$ of different fabric wave and the inset is the corresponding peak ( $\mathrm{min}$ ) 
densities of woven fabrics $\left(\mathrm{g} / \mathrm{cm}^{3}\right)$ and of fibers $\left(\mathrm{g} / \mathrm{cm}^{3}\right)$, respectively. $M_{\text {fabric }}$ is the mass of the fabric per square meter $\left(\mathrm{g} / \mathrm{m}^{2}\right)$ and $T_{\text {fabric }}$ - the thickness of the fabric $(\mathrm{mm})$.

The reason is that the smaller pores led to the higher capillary pressure and the greater liquid advancement [26, 27], causing the less fragrance residue. In addition to pore structure, the wettability of a fabric by liquid is of great importance in terms of its liquid absorption capacity [22]. Between the two fabrics, the wettability of plain fabric was higher than twill fabric based on the test results (i.e. sample \# $1 H_{\text {wrap }}=70.1$ $\pm 1.3 \mathrm{~mm}, H_{\text {weft }}=57.4 \pm 1.1 \mathrm{~mm}$; sample \# $4 H_{\text {wrap }}=$ $67.93 \pm 1.4 \mathrm{~mm}, H_{\text {weft }}=55.57 \pm 1.06 \mathrm{~mm}$ ). Thus, it turned out that plain fabrics had the shorter fragrance retention than twill fabrics.

The effect of fabric density on fragrance retention From the result of figure 6 , it is found that $R 9$ increased with the increasing of fabric density. Similarly, as revealed in figure 7 , the higher the fabric density was, the smaller the drying rate would be, the longer the drying time required. All above indicated that fabric with the higher fabric density had the bet-

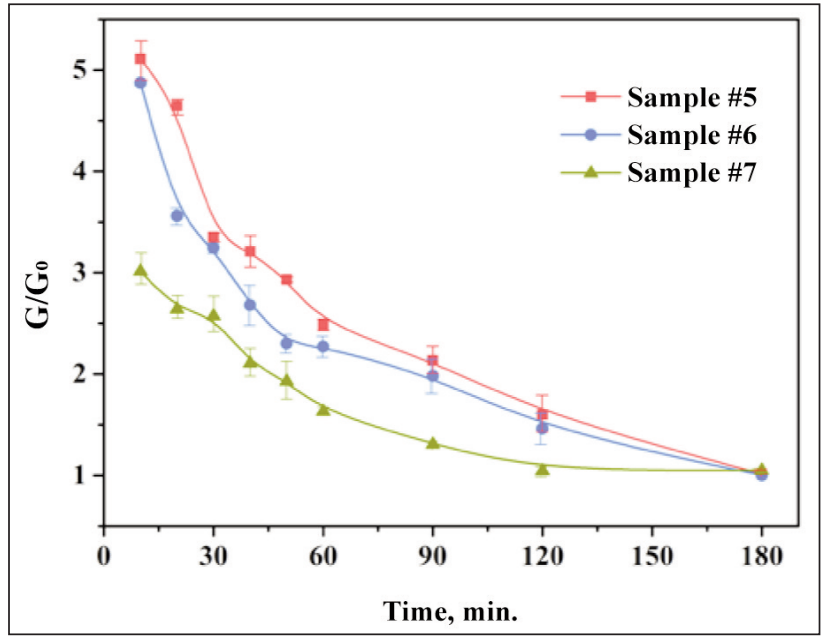

Fig. 6. The resistor value of different fabric densities

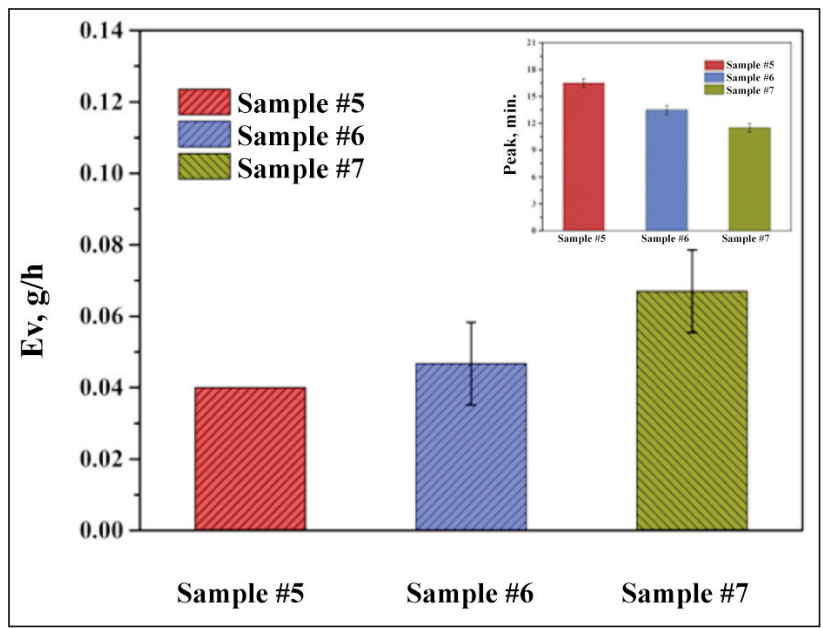

Fig. 7. The drying rate $\mathrm{Ev}(\mathrm{g} / \mathrm{h})$ of different fabric densities and the inset is the corresponding peak ( $\mathrm{min}$ ) ter fragrance retention. According to the test, the wicking properties of fabrics increased as the fabric densities decreased (i.e. sample \# $5 H_{\text {wrap }}=64.6 \pm$ $1.5 \mathrm{~mm}, H_{\text {weft }}=53.4 \pm 1.5 \mathrm{~mm}$; sample \# $6 H_{\text {wrap }}=$ $71.5 \pm 1.2 \mathrm{~mm}, H_{\text {weft }}=61.3 \pm 1 \mathrm{~mm}$; sample \# $7 H_{\text {wrap }}=$ $78.2 \pm 1.3 \mathrm{~mm}, H_{\text {weft }}=65.6 \pm 1.3 \mathrm{~mm}$ ). It proved that the lower fabric density led to the better liquid transport with a certain range. Similar trends can be found in previous studies [29]. The truth is that in the case of a certain amount of perfume, the inter-yarn spaces of fabrics which have the lower fabric densities would be filled with more liquid, and it was available for perfume diffusion [30]. In the experiment, the inter-yarn spaces became smaller when the fabric densities became higher. The diffusion and drying process slowed down, making the fragrance remain for a longer time.

The effect of yarn count on fragrance retention

The results of fragrance retention detection and drying rate test for different yarn counts are shown in figures 8 and 9 , respectively. As the yarn count of fabric decreased, the R9 and peak increased while the drying rate decreased, which mirrored the longer

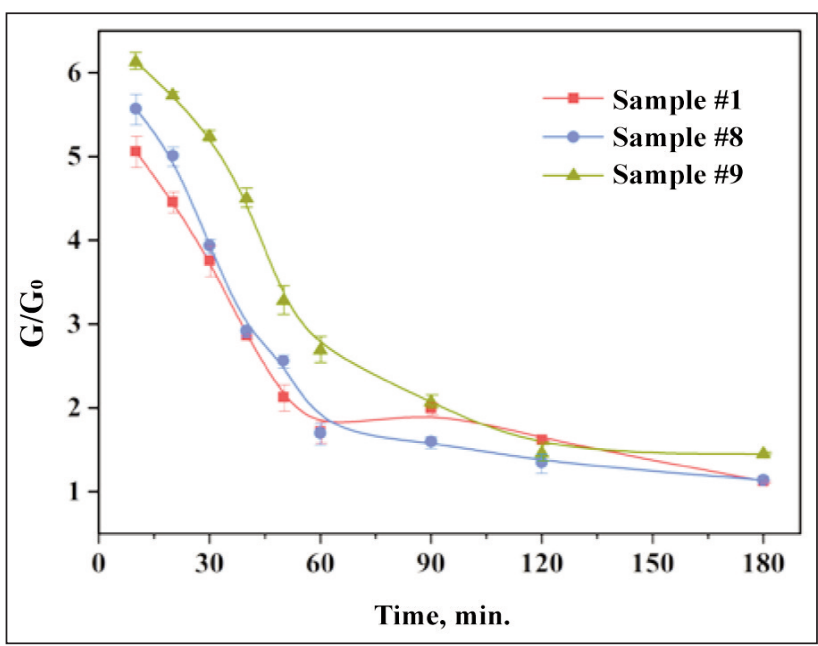

Fig. 8. The resistor value of different yarn counts

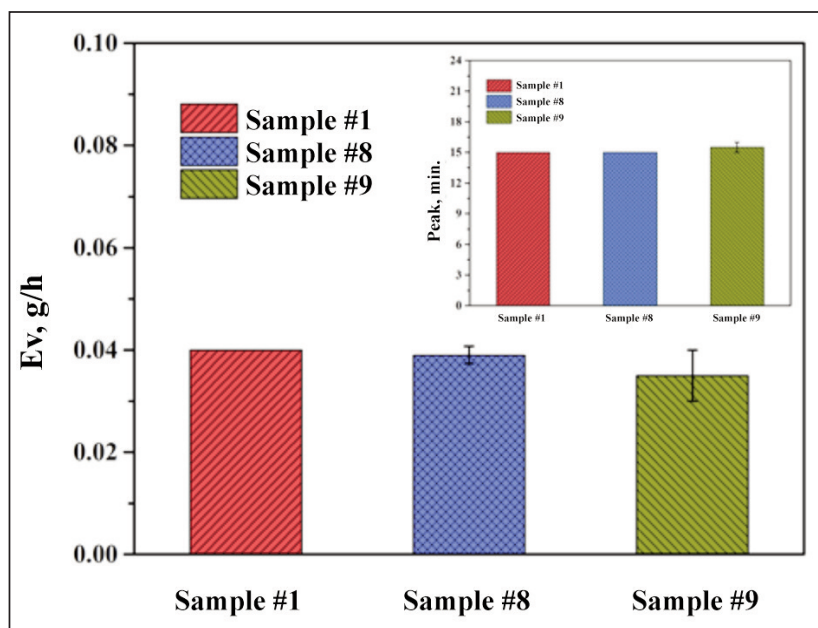

Fig. 9. The drying rate $\mathrm{Ev}(\mathrm{g} / \mathrm{h})$ of different yarn counts and the inset is the corresponding peak ( $\mathrm{min}$ ) 
fragrance retention. And the data of wicking property test indicates that the smaller yarn count resulted in a worse wicking property (i.e. sample \# $1 H_{\text {wrap }}=70.1 \pm$ $1.3 \mathrm{~mm}, H_{\text {weft }}=57.4 \pm 1.1 \mathrm{~mm}$; sample \# $8 H_{\text {wrap }}=$ $69.43 \pm 1.4 \mathrm{~mm}, H_{\text {weft }}=54.63 \pm 1.2 \mathrm{~mm}$; sample \# 9 $H_{\text {wrap }}=57.7 \pm 0.7 \mathrm{~mm}, H_{\text {weft }}=46.4 \pm 1.5 \mathrm{~mm}$ ). That is the moisture transmitted faster in the fabric with the higher yarn count. In the case of diffusion along the fiber, the absorbed liquid diffused from the interior of the fiber to its surface $[23,30]$. Therefore, the finer fiber would absorb less perfume, and the diffusion process from the interior to its surface would become faster. Moreover, under the condition of a constant perfume, with the increasing of the yarn count, there would be more liquid in the inter-yarn space which contributed to moisture transmission, likewise [29].

\section{CONCLUSIONS}

It concluded that the effect of fabric parameters on fragrance retention was attributed to the water absorption, retention properties of fibers, and the diffusion of the perfume among yarns. The fragrance retention was related to the drying rate and the wicking property. Fabrics with the higher cotton content had the better fragrance retention, for cotton fibers had better water retention properties and polyester fibers had better moisture transmission properties.
Twill fabrics remained fragrance longer than plain fabrics. Since the lower porosity of plain fabrics caused the higher capillary pressure, it could contribute to a greater liquid advancement. As the fabric density increased, the fragrance retention increased. The reason is that the less thread spacing (i.e. the higher fabric density) resulted in the worse wicking in fabrics, leading to less perfume volatile. Except that, when the yarn count increased, there would be less perfume absorbed in and faster liquid diffusion from the inside to the fiber surface, which finally caused less residue of fragrance. This study provides a useful reference for prolonging the fragrance retention in actual wear, which may be applied in fields such as sport and business.

\section{ACKNOWLEDGEMENTS}

This study is financially supported by the Natural Science Foundation of Zhejiang Province (LQ19E030021), the Zhejiang Sci-Tech University Scientific Research Foundation (17072190-Y), the Special Foundation for Excellent Doctor of Zhejiang top priority discipline of textile science and engineering of the priority discipline (2017YBZX13), the Clothing National Experimental Teaching Demonstrating Center (zx2019006), and the Clothing Culture Innovation Team of Zhejiang Sci-Tech University (11310031282006).

\section{REFERENCES}

[1] Toller, S.V., Dodd, G.H., Perfumery: The psychology and biology of fragrance, In: Springer Science and Business Media, 2012

[2] Doty, R.L., Olfactory communication in humans, In: Chemical Senses, 1981, 6, 4, 351-376

[3] Kayar, M., Effects of perfume on mechanical and color properties of cotton fabrics, In: International Journal of Clothing Science and Technology, 2015, 27, 1, 6-16

[4] Yang, Y., Wei, K., Lv, D.P, Effect of lavender essential oil inhalation on primary insomnia patients, In: China Medical Herald, 2016, 13, 24, 144-147

[5] Drechsel, D.A., Towle, K.M., Fung, E.S., Novick, R.M., Paustenbach, D.J., Monnot, A.D., Skin sensitization induction potential from daily exposure to fragrances in personal care products, In: Dermatitis, 2018, 29, 6, 324-331

[6] Schubert, H.J., Skin diseases in workers at a perfume factory, In: Contact Dermatitis, 2006, 55, 2, 81-83

[7] Zhao, H., Fei, X., Cao, L., Zhang, B., Liu, X., The fabrication of fragrance microcapsules and their sustained and broken release behavior, In: Materials, 2019, 12, 3, 393-406

[8] Gao, M.X., Wang, X.N., Gong, Y., Liao, Q., Application of electronic nose in cotton fabric odor detection, In: Sensors and Microsystems, 2011, 30, 6, 33-35

[9] Shi, H., Zhang, M., Adhikari, B., Advances of Electronic Nose and Its Application in Fresh Foods $\square$ A review, In: Critical Reviews in Food Science and Nutrition, 2018, 58, 16, 2700-2710

[10] Esteves, C.H.A., Iglesias, B.A., Ogawa ,T., Araki, K., Hoehne, L., Gruber, J., Identification of tobacco types and cigarette brands using an electronic nose based on conductive polymer/porphyrin composite sensors, In: ACS Omega, 2018, 3, 6, 6476-6482

[11] Rusinek, R., Gancarz, M., Krekora, M., Nawrocka, A., A novel method for generation of a fingerprint using electronic nose on the example of rapeseed spoilage, In: Journal of Food Science, 2019, 84, 1, 51-58

[12] Wilson, A.D., Baietto, M., Applications and advances in electronic-nose technologies, In: Sensors, 2009, 9, 7, 5099-5148

[13] Wilson, A.D., Baietto, M., Advances in electronic-nose technologies developed for biomedical applications, In: Sensors, 2011, 11, 1, 1105-1176

[14] Capelli, L., Sironi, S., Rosso, R.D., Electronic noses for environmental monitoring applications, In: Sensors, 2014, 14, 11, 19979-20007

[15] Sariişik, M., Okur, S., Asma, Ş., Odor adsorption kinetics on modified textile materials using quartz microbalance technique, In: Acta Physica Polonica A, 2012, 121, 1, 243-246 
[16] Soria, A.C., García-Sarrió, M.J., Sanz, M.L., Volatile sampling by headspace techniques, In: TrAC Trends in Analytical Chemistry, 2015, 71, 85-99

[17] Aftel, M., Essence and alchemy: a book of perfume. In: North Point Press, 2002

[18] Teixeira, M.A., Rodríguez, O., Rodrigues, S., Martins, I., Rodrigues, A.E., A case study of product engineering: Performance of microencapsulated perfumes on textile applications, In: AIChE Journal, 2012, 58, 6, 1939-1950

[19] Yu, H.C., Wang, J., Zhang, H.M, Yu, Y., Yao, C., Identification of green tea grade using different feature of response signal from E-nose sensors, In: Sensors and Actuators B: Chemical, 2008, 128, 2, 455-461

[20] Saricam, C., Kalaoğlu, F., Investigation of the wicking and drying behaviour of polyester woven fabrics, In: Fibres and Textiles in Eastern Europe, 2014, 22, 105, 73-78

[21] Namligöz, E.S., Çoban, S., Bahtiyari, M.I., Comparison of moisture transport properties of the various woven fabrics, In: Tekstil Ve Konfeksiyon, 2010, 20, 2, 93-100

[22] Hsieh, Y. L., Liquid transport in fabric structures, In: Textile Research Journal, 1995, 65, 5, 299-307

[23] Das, B., Das, A., Kothari, V.K., Fanguiero, R., M. de Araújo, Moisture transmission through textiles part I: processes involved in moisture transmission and the factors at play, In: AUTEX Research Journal, 2007, 7, 2, 100-110

[24] Zupin, Z., Hladnik, A., Dimitrovski, K., Prediction of one-layer woven fabrics air permeability using porosity parameters, In: Textile Research Journal, 2011, 82, 2, 117-128

[25] Atasağun, H.G., Okur, A., Akkan, T., Akkan, L.Ö., A test apparatus to measure vertical wicking of fabrics-a case study on shirting fabrics, In: The Journal of The Textile Institute, 2016, 107, 12, 1483-1489

[26] Yanılmaz, M., Kalaoğlu, F., Investigation of wicking, wetting and drying properties of acrylic knitted fabrics, In: Textile Research Journal, 2012, 82, 8, 820-831

[27] Petrulyte, S., Baltakyte, R., Liquid sorption and transport in woven structures, In: Fibres and Textiles in Eastern Europe, 2009, 17, 2, 39-45

[28] Hasan, M.M.B., Calvimontes, A., Synytska, A., Dutschk, V., Effects of topographic structure on wettability of differently woven fabrics, In: Textile Research Journal, 2008, 78, 11, 996-1003

[29] Mhetre, S., Parachuru, R., The effect of fabric structure and yarn-to-yarn liquid migration on liquid transport in fabrics, In: The Journal of the Textile Institute, 2010, 101, 7, 621-626

[30] Minor, F.W., Schwartz, A.M., Wulkow, E.A., Buckles, L.C., The migration of liquids in textile assemblies part II: the wicking of liquids in yarns, In: Textile Research Journal, 1959, 29, 12, 931-939

Authors:

LEI DU ${ }^{1,2}$, FU-XIANG WANG ${ }^{1}$, JIA-LI YANG ${ }^{1}$, ZHUO-YING SHEN ${ }^{1}$, WEI-GUO ZHAO ${ }^{1}$, FENG-YUAN ZOU ${ }^{1,2}$, HAI-FENG ZHU1,2, SU-HONG XU ${ }^{3}$

${ }^{1}$ School of Fashion Design \& Engineering, Zhejiang Sci-Tech University, 310018, Hangzhou, China

${ }^{2}$ Zhejiang Provincial Research Center of Clothing Engineering Technology, 310018, Hangzhou, China

${ }^{3}$ College of Fashion and Design, Donghua University, 200051, Shanghai, China

Corresponding author:

LEI DU

e-mail: dulei@zstu.edu.cn 